\title{
EFFECT OF SEAWEED EXTRACT AND AMINO ACIDS ON GROWTH AND PRODUCTIVITY AND SOME BIOCOSTITUENTS OF COMMON BEAN (Phaseolus vulgaris L) PLANTS
} Zewail, R. M. Y. Botany Department Fac. of Agric. Benha Univ. Egypt

\begin{abstract}
Two filed experiments were carried out at a private farm in Behaira Governorate, Egypt during 2012 and 2013 summer seasons. Experiments aimed to study the effect of two widely marketing (commercial safe compounds). First, is a seaweed extract (with commercial name of sea weed) at 1,2 and $4 \mathrm{ml} / \mathrm{l}$ while the second is a mixture of free amino acids (with plant origin and commercially name is sway) at 2,4and $8 \mathrm{ml} / \mathrm{l}$ and seaweed at $2 \mathrm{ml} / \mathrm{l}+$ amino acids at $4 \mathrm{ml} /$. The two compounds were applied as foliar spray three times on common bean plant (Phaseolus vulgaris L.) starting at 25 days of plant age with 10 days intervals between each spray and others. The obtained results clearly indicate that different applied treatments increased estimated or measured growth characteristics i.e., plant height, stem diameter, number of branches and leaves/ plant, total leaf area/plant, dry weight of shoots and specific growth rate as well as paralley increase of photosynthetic pigments and total chlorophyll SPDS with increasing seaweed and amino acid sprayed levels at the age of 65 days after sowing during 2012 and 2013 seasons. As for the yield and yield components i.e., number of pods/plant, pod weight $(\mathrm{g})$, number of seeds per pod, number of fully seeds /plant, , weight of 100 seeds (g), number of seeds/ plant, seed yield (g) /plant and the harvest index. Also, biochemical constituents of $\mathrm{N}, \mathrm{P}, \mathrm{K}, \mathrm{Mg}, \mathrm{Ca}, \mathrm{Fe}, \mathrm{Zn}$, Total carbohydrates and crude protein in leaves at 65 days of plant age were existed in the two assigned seasons. In addition, the most effective treatments was that of sea weed at $2 \mathrm{ml} / \mathrm{l}$ combined with the amino acids at $4 \mathrm{ml} / \mathrm{l}$ was the most effective treatment in this respect.
\end{abstract}

Keywords: common bean, seaweed, amino acids, growth, yield, minerals and crude protein.

\section{INTRODUCTION}

Common bean is important legume in worldwide for direct human consumption. The crop is consumed principally for its dry (mature) beans, shell beans (seeds at physiological maturity) and green pods. When consumed as seed, beans constitute an important source of dietary protein (22\% of seed weight) that complements cereals for over half a billion people mainly in the Africa. Annual production of dry beans is around 15 million tons and average yield is $700 \mathrm{~kg}$ ha, although yields in certain countries reach $2000 \pm 3000 \mathrm{~kg}$ haÿ1. (Şehirali, 1988).

Seaweed extract (SWE) is a new generation of natural organic fertilizers containing highly effective nutritious and promotes faster germination of seeds and increase yield and resistant ability of many crops. Unlike, chemical fertilizers, extracts derived from seaweeds are biodegradable, nontoxic, nonpolluting and non-hazardous to humans,

Corresponding authors: Reda Zewail Botany Dpt., Fac. Agric. Benha Univ. Egypt. Website: www..bu.edu.eg/staff member/reda.zewail6 edu mail: Reda.zewail@fagr.bu.edu.eg 
animals and birds Dhargalkar and Pereira (2005). Liquid fertilizers derived from natural sources like seaweed are found to be viable alternatives to fertilizing input for agricultural crops due to its high level of organic matter, micro and macro elements, vitamins, fatty acids, also rich in growth regulators Crouch and Staden (1993). The growth promoting effect of liquid extract of seaweeds on germination vegetative growth and biochemical characteristics are being carried out in some economic vegetables and fruits (Khan et al.,2009).

Seaweed extract application for different crops has a great importance due to its content with high levels of organic matter, micro elements ( $\mathrm{Fe}, \mathrm{Cu}, \mathrm{Zn}, \mathrm{Co}, \mathrm{Mo}, \mathrm{Mn}$ and $\mathrm{Ni}$ ), vitamins and amino acids and also, is being rich in growth regulators such as auxins, cytokinins and gibberellins (Khan et al.,2009). Exogenous application of seaweed extract has already been shown to enhance plant growth, yield and its quality, as well (Abdel Mawgoud et al.,(2010) on watermelon ; Shehata et al.,(2011) on Celeriac Plant and (Abou El-Yazied et al.,(2012) on Snap Bean).

Biostimulants Sea weed extract (SWE) can promote plant growth may be due to : I)- activate root cells at the same time stimulate biosynthesis of endogenous cytokinins from roots (Schmidt 2005). II)- enhancing leaf water status, some plant nutrients uptake, shoot growth and root pull strength (Demir et al. 2004). III)- altering hormonal balances and favor cytokinins and auxins production (Schmidt 2005). IV)- enhancement of antioxidant enzymes (SOD, GR, ASP) for protection against adverse environmental conditions (Schmidt 2005). V)- stimulation the biosynthesis of Tocopherol, ascorbic acid and carotenoids in chloroplast which protect photosynthetic apparatus of PSII (Zhang and Schmidt 2000). VI)- protection of plant cells from lipid peroxidation and in activation of enzymes that occur under stress (Smirnoff 1995). VII)- stimulation stem elongation and exhibits auxin-like activity. (Crouch and Van-Staden 1993). VIII)- reduced uptake of $\mathrm{NaCl}$ (Nabati 1994) while increased $\mathrm{K}$ and $\mathrm{Ca}$ content in the leaves (Demir et al. 2004). IX)stimulation of chlorophyls biosynthesis (Garbay and Churin 1996) and regulation cell membrane components under drought stress (Yan 1993). X)inhibits activity of free radical groups which are major elements for chlorophyll degradation (Fletcher et al. 1988). XI)- stimulation the uptake of $\mathrm{N}, \mathrm{P}, \mathrm{K}, \mathrm{Mg}$, $\mathrm{Ca}, \mathrm{Zn}, \mathrm{Fe}$ and $\mathrm{Cu}$ by the plants that alleviate the inhibitory effect of $\mathrm{Na}$ toxicity and restored growth (Nelson and Van-Staden 1984). XII)- promoted the accumulation of reducing sugars which increased wilting resistance through enhancing osmotic pressure inside plant. In addition nucleic acids metabolism were stimulated (O,Donnell 1973). XIII)- Stimulation of chloroplast development and enhancing phloem loading and delay senescence (Demir, et al. 2004 ).

Also, amino acids as organic nitrogenous compounds are well known to stimulate cell growth and acting as buffers maintaining favorable $\mathrm{pH}$ value within the plant cell as well as synthesizing other organic compounds Opike and Rolfe (2005).Amino acids in essential quantities is well known as a means have positive effects on plant growth, yield and quality of different crops. Amino acids are fundamental ingredients in the process of protein synthesis, formation of plant tissue and chlorophyll synthesis, similar effect 
and findings about amino acids were indicated by Abo Sedra et al., (2010) on strawberry and El-Desouky et al., (2011) on tomato. In addition, amino acids are precursors or activators of phytohormones and growth substance (i.e., alternative routes of IAA synthesis exist in plants, all starting from Tryptophan (Marschner, 1995 and Opike and Rolfe, 2005). The biosynthesis of cinamic acids (which are the starting materials for the synthesis of phenols like salcylic acid ) are derived from phenylalanine and tyrosine. Tyrosine is hydroxy $L$ phenyl amino acid that is used to build neurotransmitters and hormones).

Thereby, due to the high economic value of common bean plants, (Phaseolus vulgaris $\mathrm{L}$ ) the present study aimed to evaluate the promoter effects of seaweed and amino acids to sustain vigorous growth and maximizing seed yield with good quality and highest protein content, as well.

\section{MATERIALS AND METHODS}

Two field experiments were conducted at Behara governorate at Baslakon village in which yearly cultivate beans for day seed production since many years ago till now during 2012 and 2013 seasons to study the effect of seaweed at 1,2 and $4 \mathrm{ml} / \mathrm{L}$ and amino acids at 2,4 and $8 \mathrm{ml} / \mathrm{l}$ as well as their combination of $2 \mathrm{ml} / \mathrm{l}$ seaweed $+4 \mathrm{ml} / \mathrm{l}$ amino acids and control with distilled water as foliar application, to study the possibility of using such costless and safety martials for maximizing growth, productivity and fruit quality of common bean (Phaseolus vulgaris L.).

Plants were sprayed 3 times with different assigned treatments; the first one was at 25 days after sowing and repeated each 10 days intervals. Randomized complete block design in three replicates was adopted herein. Seeds were sown in $3^{\text {rd }}$ and $5^{\text {th }}$ of march during first and second seasons, respectively. All cultural practices for growing common bean plants were performed as recommended (in the region of production) for dry bean seed production (including irrigation, nutrition, pest and diseases control).

\section{Seaweed extract:}

Seaweed extract producted by Orbital for Agrochemicals, 24 A Obour Bldgs - Salah Salem Cairo, Egypt. Contains minerals as ( Fe, $\mathrm{Zn}, \mathrm{Cu}, \mathrm{Mn}$ and Mo), vitamins, enzymes, amino acids, sugars, and plant hormones,(i.e., auxins, cytokinins and gibberellins) was used.

\section{Amino acids composition:}

\section{SWAY is the commercial name}

$10 \% \mathrm{~L}-\alpha$ free amino acids is a brown liquid with $\mathrm{PH}$ of $5-5.5$ and specific gravity of $1.25 \mathrm{~g} / \mathrm{ml}$. Also, it contains $20.4 \% \mathrm{w} / \mathrm{w}$ organic matter content, $10 \% \mathrm{w} / \mathrm{w}$ free amino acids, $3 \% \mathrm{w} / \mathrm{w}$ total nitrogen and $3 \% \mathrm{w} / \mathrm{w}$ organic nitrogen was used as a source for amino acids mixture . producted by Orbital for Agrochemicals, 24 A Obour Bldgs - Salah Salem Cairo, Egypt. 


\section{Experimental parameters:}

1) Morphological characteristics:

Different morphological characteristics of common bean (Phaseolus vulgaris L.) plants at 65 days after sowing were measured and calculated. Ten plants from each treatment were randomly taken for measurements.

The following characteristics were inspected:

- Plant height $(\mathrm{cm})$, Stem diameter $(\mathrm{cm})$ at the first internode above soil surface , Number of branches / plant. Number of leaves / plant., Total dry weight of main stem , branches and leaves (g) / plant, Total leaf area $\left(\mathrm{cm}^{2}\right)$ / plant using the disk method according to (Derieux et al., 1973).,Specific leaf weight/plant $\left(\mathrm{mg} / \mathrm{cm}^{2}\right)$ was calculated according to the following equation:

Specific leaf weight/plant $(\mathrm{mg} / \mathrm{cm} 2)=$ Leaves dry weight $\mathrm{g} /$ plant $/$ Leaf area /plant $\left(\mathrm{cm}^{2}\right)$.

2) Photosynthetic pigments:

Chlorophyll $\mathrm{a}, \mathrm{b}$ and carotenoids were using calorimetrically determine in the common bean leaves at 65 days after sowing during 2012 and 2013 seasons according to the methods described by (Wettstein, 1957) and calculated as $\mathrm{mg} / \mathrm{g}$ fresh weight. Also, total chlorophylls (SPDS) was determined by using chlorophyll meter (Model SPAD 402).

\section{3) Yield and yield components:}

At harvest time i.e. 100 days after sowing ten plants were randomly chosen from each plot to measure and /or count yield characteristics i.e. Number of pods/plant, pod weight (g), number of seeds/plant., fully seeds/pod, weight of 100 seeds $(\mathrm{g})$, number of seeds/plant, seeds yield /plant (g) and Harvest index = Economic yield / Biological yield .

\section{4) Chemical analysis:}

Total nitrogen was determined in the dry matter of common bean leaves at 65 days after sowing and in seeds at the harvest time during 2012and 2013 seasons, by using wet digestion according to (Piper, 1947), using microkjeldahl as described by (Horneck and Miller, 1998), then calculated as \% dry weight and calculated crude protein in leaves and in seeds at harvest time. Phosphorus, was calorimetrically determined according to the method of (Sandell, 1950) and calculated as \% of dry weight. Potassium, it was determined by the flame photometer model Carl-Zeiss according to the method described by (Horneck and Hanson, 1998) and calculated as \% dry weight. Calcium and Magnesium, Calcium and Magnesium were determined by versinate, using ammonium periorate and Eriochrome Black T as indicator, respectively, according to (Jackson, 1967) and calculated as \% of dry weight. $\mathrm{Fe}$ and $\mathrm{Zn}$ as described by A.O.A.C. (1990)The total carbohydrate were determined colorimetrically according to the method of (Dubois et al., 1956 and A.O.A.C., 1990).

\section{5) Statistical analysis}

All data were statistically and the means were compared using the Least Significant Difference Test (L.S.D.) at 5\% level according to Snedecor and Corchran (1980). 


\section{RESULTS AND DISCUSSION}

\section{Growth characteristics:}

Data in Table (1) indicate that different applied seaweed and amino acids applied treatments i.e. seaweed at 1, 2 and $4 \mathrm{ml}$ and amino acids at 2, 4 and $8 \mathrm{ml} / \mathrm{l}$ as well as the combination of seaweed at $2 \mathrm{ml} / \mathrm{l}+$ amino acids at $4 \mathrm{ml} / \mathrm{l}$ significantly increased growth characteristics (i.e., plant height, stem diameter, number of branches, number of leaves, total leaf area, dry weight and specific leaf weight (S.L.W)) at 65 days after sowing during 2012 and 2013 seasons. Also, it could be noticed that different growth characteristics showed their highest values with combination of seaweed at $2 \mathrm{ml} / \mathrm{l}$ with amino acids at $4 \mathrm{ml} / \mathrm{l}$ during 2012 and 2013 seasons Was the most effective in this respect.

Table (1).Effect of applied seaweed and amino acids on growth characteristics of common bean (Phaseolus vulgaris $L$.) plants at 65 days after sowing during 2012 and 2013 seasons.

\begin{tabular}{|c|c|c|c|c|c|c|c|c|c|c|c|c|c|c|}
\hline \multirow{2}{*}{ Characteristics } & \multicolumn{2}{|c|}{$\begin{array}{l}\text { Plant } \\
\text { height } \\
\text { cm }\end{array}$} & \multicolumn{2}{|c|}{$\begin{array}{l}\text { Stem } \\
\text { diameter } \\
\text { cm }\end{array}$} & \multicolumn{2}{|c|}{$\begin{array}{c}\text { Number } \\
\text { of } \\
\text { branches }\end{array}$} & \multicolumn{2}{|c|}{$\begin{array}{c}\text { Number of } \\
\text { leaves }\end{array}$} & \multicolumn{2}{|c|}{$\begin{array}{l}\text { Total leaf } \\
\text { area } \mathrm{cm}^{2}\end{array}$} & \multicolumn{2}{|c|}{\begin{tabular}{|c|} 
Dry \\
weights (g)
\end{tabular}} & \multicolumn{2}{|c|}{\begin{tabular}{|c|} 
Specific \\
leaf weight \\
(SLW)
\end{tabular}} \\
\hline & 2012 & 2013 & 2012 & 2013 & 2012 & 2013 & 2012 & 2013 & 2012 & 2013 & 2012 & 2013 & 2012 & 2013 \\
\hline $\begin{array}{lll}\text { Seaweed at } 1 \\
\mathrm{ml} / / \mathrm{l}\end{array}$ & 60.25 & 62.30 & 2.15 & 2.23 & 6.33 & 6.66 & 33.33 & 35.66 & 1520.2 & 1582.1 & 90.43 & 92.58 & 0.059 & 0.059 \\
\hline $\begin{array}{l}\text { Seaweed at } 2 \\
\mathrm{ml} / /\end{array}$ & 62.35 & 63.55 & 2.20 & 2.30 & 6.66 & 7.00 & 35.66 & 36.33 & 1545.1 & 1560.2 & 95.62 & 99.60 & 0.062 & 0.064 \\
\hline $\begin{array}{l}\text { Seaweed at } 4 \\
\mathrm{ml} / / \mathrm{l}\end{array}$ & 70.72 & 71.24 & 2.41 & 2.52 & 7.00 & 7.66 & 40.66 & 42.00 & 1553.4 & 1572.3 & 105.4 & 110.9 & 0.068 & 0.071 \\
\hline $\begin{array}{l}\text { Amino acids at } \\
2 \mathrm{ml} / \mathrm{l}\end{array}$ & 6 & 67.29 & 2.48 & 2.51 & 6.33 & 7.00 & 42.33 & 43.66 & 1562.3 & 1585.6 & 95.56 & 100.7 & 0.061 & 0.064 \\
\hline $\begin{array}{l}\text { Amino acids at } \\
4 \mathrm{ml} / \mathrm{l}\end{array}$ & .24 & 70.39 & 2.65 & 2.72 & 7.00 & 7.66 & .33 & 46.00 & 1581.5 & 1590.8 & 101.2 & 108.5 & 0.064 & 0.068 \\
\hline $\begin{array}{l}\text { Amino acids at } \\
8 \mathrm{ml} / \mathrm{l}\end{array}$ & 7 & 73.42 & 75 & 2.82 & 7.66 & 8.00 & 46.66 & 47.33 & 1562.3 & 1602.9 & 110.3 & 115.6 & 0.071 & 0.072 \\
\hline $\begin{array}{l}\text { Seaweed at } 2 \\
\mathrm{ml} / \mathrm{l}+\text { amino acid } \\
\text { at } 4 \mathrm{ml} / \mathrm{l}\end{array}$ & 75.24 & 77.52 & 3.01 & 3.22 & 8.33 & 9.00 & 48.33 & 49.66 & 1655.7 & 1680.7 & 115.7 & 120.9 & 0.070 & 0.072 \\
\hline Control & 53.22 & 55.48 & 2.00 & 2.03 & 5.33 & 6.00 & 30.00 & 33.33 & 1240.4 & 1320.2 & 85.42 & 88.55 & 0.069 & 0.067 \\
\hline LSD at $5 \%$ & 2.02 & 2.26 & 0.12 & 0.15 & 0.25 & 0.45 & 1.45 & 1.52 & 12.14 & 15.22 & 3.42 & 4.02 & 0.003 & 0.005 \\
\hline
\end{tabular}

In this respect, the obtained increase of these traits could be attributed to the effect of main component of amino acids(in the two applied materials) these are essentially required for the biosynthesis of a large variety of non-protein nitrogenous materials, i.e. pigments, vitamins, coenzymes, purine and pyrimidine bases (Bidwell, 1980). Also, amino acids could directly or indirectly influence the physiological activities of plant growth and development, through their regulatory effects on production of gibberellins in plant tissues (Waller and Nowaki, 1978). In this concern, ElGhamry et al. (2009) and Hanafy et al., (2010) cleared that foliar application of amino acids significantly increased plant height as well as number of leaves and branches/plant of faba bean plants. In addition, seaweed products 
exhibit growth stimulating activities, and the use of seaweed formulations as bio stimulants in crop production is well established. Bio stimulants are defined as materials, other than fertilizers, that promote plant growth when applied in small quantities and are also referred to as metabolic enhancers (Zhang and Schmidt 1997). Seaweed extract contained components such as macro- and micro element nutrients, amino acids, vitamins, cytokinins and auxins like growth substances in which affect cellular metabolism in treated plants leading to enhanced growth and crop yield.

\section{2- Photosynthetic pigment concentrations:}

Data in Table (2) clearly indicate that different applied treatments i.e. seaweed at 1, 2\& $4 \mathrm{~m} / \mathrm{l}$ and amino acids at 2, $4 \& 8 \mathrm{ml} / \mathrm{l}$ as well seaweed at 2 $\mathrm{ml} / \mathrm{l}+$ amino acids at $4 \mathrm{ml} / \mathrm{l}$ increased photosynthetic pigments in bean leaves and SPDS at 65 days after sowing during 2012 and 2013 seasons. Also, it is obvious that the highest value in these traits was existed with seaweed at 2 $\mathrm{ml} / \mathrm{l}+$ amino acids at $4 \mathrm{ml} / /$ during the two assigned seasons.

Table(2).Effect of seaweed and amino acids treatments on photosynthetic pigment contents $\mathrm{mg} / \mathrm{g}$ f.w. in common bean leaves (Phaseolus vulgaris $L$.) at 65 days after sowing during 2012 and 2013 seasons.

\begin{tabular}{|c|c|c|c|c|c|c|c|c|c|c|}
\hline \multirow{2}{*}{ Treatments } & \multicolumn{2}{|c|}{$\begin{array}{l}\text { Chlorophyll } \\
\text { A mg/g f.w. }\end{array}$} & \multicolumn{2}{|c|}{$\begin{array}{l}\text { Chlorophyll } \\
\text { b mg/g f.w. }\end{array}$} & \multicolumn{2}{|c|}{$\begin{array}{c}\text { Cartnoides } \\
\mathrm{mg} / \mathrm{g} \text { f.w. }\end{array}$} & \multicolumn{2}{|c|}{$\begin{array}{c}\text { chlorophyll } \\
a+b \mathrm{mg} / \mathrm{g} \\
\text { f.w. }\end{array}$} & \multicolumn{2}{|c|}{$\begin{array}{c}\text { Total } \\
\text { chlorophyll } \\
\text { SPDS }\end{array}$} \\
\hline & 2012 & 2013 & 2012 & 2013 & 2012 & 2013 & 2012 & 2013 & 2012 & 2013 \\
\hline Seaweed at $1 \mathrm{ml} / \mathrm{l}$ & 1.25 & 1.36 & 0.522 & 0.582 & 0.510 & 0.480 & 1.77 & 1.94 & 95.12 & 96.22 \\
\hline Seaweed at $2 \mathrm{ml} / \mathrm{l}$ & 1.32 & 1.41 & 0.632 & 0.724 & 0.650 & 0.620 & 1.95 & 2.13 & 98.25 & 99.14 \\
\hline Seaweed at $4 \mathrm{ml} / \mathrm{l}$ & 1.42 & 1.52 & 0.720 & 0.752 & 0.702 & 0.715 & 2.14 & 2.27 & 100.28 & 105.25 \\
\hline Amino acids at $2 \mathrm{ml} / \mathrm{I}$ & 1.3 & 1.40 & 0.622 & 0.650 & 0.601 & 0.615 & 1.94 & 2.05 & 96.32 & 98.43 \\
\hline $\operatorname{mino}$ acids at $4 \mathrm{ml} / \mathrm{l}$ & 1.4 & 1.56 & & & & & 2.13 & 2.36 & .23 & 102.47 \\
\hline Amino acids at $8 \mathrm{ml} / \mathrm{l}$ & 1.52 & 1.62 & 785 & 815 & 0. & 0. & 2.31 & 2.44 & 110.52 & 112.72 \\
\hline $\begin{array}{l}\text { Seaweed at } 2 \mathrm{ml} / /+ \\
\text { amino acid at } 4 \mathrm{ml} / /\end{array}$ & 1.61 & 1.92 & 5 & 0.892 & 2 & 0 & 2.43 & 2.81 & 6 & 1 \\
\hline Control & 1.10 & 1.12 & 0.420 & 0.450 & 0.320 & 0.352 & 1.52 & 1.57 & 82.14 & 85.25 \\
\hline LSD at $5 \%$ & 0.11 & 0.15 & 0.125 & 0.185 & 0.152 & 0.164 & 0.245 & 0.286 & 3.15 & 3.58 \\
\hline
\end{tabular}

In this respect, amino acids and SWE treatment are not only building blocks of proteins but also participate in many metabolic networks that control growth and adaptation to the environment Hussein et al.(1992). They are important in many biological molecules, such as forming parts of coenzymes, or as precursors for the biosynthesis of molecules such as glutamine and ornithine, which are precursors for nucleotides and polyamines, respectively (Alcázar et al ,2010) and also serve as major transport molecules of nitrogen from vegetative to reproductive tissues. Biostimulants Sea weed extract (SWE) can promote plant growth may be due to : I)- activate root cells at the same time stimulate biosynthesis of endogenous cytokinins from roots (Schmidt 2005). II)- enhancing leaf water status, some plant nutrients uptake, shoot growth and root pull strength (Demir et al. 2004). III)- altering hormonal balances and favor cytokinins and auxins production (Schmidt 2005). IV)- enhancement of antioxidant enzymes (SOD, GR, ASP) for protection against adverse environmental conditions 
(Schmidt 2005). V)- stimulation the biosynthesis of Tocopherol, ascorbic acid and carotenoids in chloroplast which protect photosynthetic apparatus of PSII (Zhang and Schmidt 2000). VI)- protection of plant cells from lipid peroxidation and in activation of enzymes that occur under stress

\section{3- Yield and yield components:}

Data in Table (3) clearly indicate that different applied treatments of seaweed and amino acids increased all yield characteristics and the dry seed yield/ plant, as well. Also, data in Table (3) showed that combination of seaweed at $2 \mathrm{ml} / /$ with amino acids at $4 \mathrm{ml} / \mathrm{l}$ gave the highest significant increase in yield and yield components and harvest index at harvest time during 2012 and 2013 seasons.

Table (3).Effect of seaweed and amino acids treatments on yield and yield components of common bean (Phaseolus vulgaris L.) plants at harvest time( i.e. 100 days after sowing) during 2012 and 2013 seasons.

\begin{tabular}{|c|c|c|c|c|c|c|c|c|c|c|c|c|c|c|}
\hline hakacteristics & $\begin{array}{l}\text { Num } \\
\text { pods }\end{array}$ & $\begin{array}{c}r \text { of } \\
\text { ant }\end{array}$ & $\begin{array}{r}\mathbf{P} \\
\text { we } \\
(\mathrm{g}\end{array}$ & $\begin{array}{l}\text { od } \\
\text { ight } \\
\text { g) }\end{array}$ & $\begin{array}{l}\text { Numb } \\
\text { seeds }\end{array}$ & $\begin{array}{l}r \text { of } \\
\text { lant }\end{array}$ & $\begin{array}{r}\text { Fu } \\
\text { seeds }\end{array}$ & $\begin{array}{l}\text { اlly } \\
\text { s/plant } \\
\text { g) }\end{array}$ & $\begin{array}{r}\text { Weig } \\
100 \mathrm{~s} \\
(\mathrm{c}\end{array}$ & $\begin{array}{l}\text { ght of } \\
\text { seeds } \\
\text { g) }\end{array}$ & $\begin{array}{r}\text { See } \\
\text { yie } \\
\text { /plan }\end{array}$ & $\begin{array}{l}\text { eds } \\
\text { eld } \\
\text { nt (g) }\end{array}$ & $\begin{array}{r}\text { Har } \\
\text { ind }\end{array}$ & $\begin{array}{l}\text { rvest } \\
\text { dex }\end{array}$ \\
\hline reatments & 2012 & 2013 & 2012 & 2013 & 2012 & 2013 & 2012 & 2013 & 2012 & 2013 & 2012 & 2013 & 2012 & 2013 \\
\hline $\begin{array}{l}\text { Seaweed at } \\
\mathrm{ml} / \mathrm{l}\end{array}$ & & 00 & 2.00 & 2.23 & 88.33 & 92.00 & 60.60 & 63.42 & 20.15 & .33 & 90.25 & 95.34 & 36.22 & 237.85 \\
\hline $\begin{array}{l}\text { Seaweed } \\
2 \mathrm{ml} / \mathrm{l}\end{array}$ & & & 2.66 & 2.73 & 90.66 & 3.33 & 65.32 & 67.45 & 22.52 & .85 & 92.66 & 95.42 & 7.24 & 438.52 \\
\hline $\begin{array}{l}\text { Seaweed at } 4 \\
\mathrm{ml} / \mathrm{l}\end{array}$ & & 33 & 2.88 & 2.95 & 92.33 & 95.66 & 63.46 & 68.89 & 24.61 & 5.72 & 95.29 & 98.47 & 38.33 & 340.25 \\
\hline $\begin{array}{l}\text { Amino acids a } \\
2 \mathrm{ml} / \mathrm{l}\end{array}$ & t & .00 & 2.55 & 2.75 & 90.00 & 92.33 & 60.25 & 67.62 & 22.72 & 23.14 & 1.27 & 96.58 & 36.55 & 538.38 \\
\hline $\begin{array}{l}\text { Amino acids at } \\
4 \mathrm{ml} / \mathrm{l}\end{array}$ & & 33 & 2.75 & 2.95 & 95.33 & 97.66 & 66.32 & 70.26 & 25.30 & .85 & 95.78 & 99.85 & 38.67 & 40.75 \\
\hline $\begin{array}{l}\text { Amino acids at } \\
8 \mathrm{ml} / \mathrm{l}\end{array}$ & 25.00 & 26.66 & 2.92 & 3.17 & 100.6 & 102.0 & 70.20 & 73.22 & 28.29 & 9.25 & 100.9 & 104.2 & 39.26 & 60.52 \\
\hline 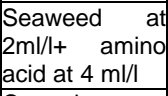 & 2 & .66 & 3.05 & 3.45 & 105.0 & 109.3 & 75.26 & 80.56 & 30.35 & .14 & $\mid 05.6$ & 10.4 & 0.25 & 543.55 \\
\hline Control & 20.00 & 21.00 & 1.75 & 2.02 & 73.33 & 75.66 & 50.12 & 52.33 & 17.60 & 18.22 & 72.26 & 75.30 & 30.22 & 232.18 \\
\hline LSD at $5 \%$ & 0.25 & 0.55 & 0.15 & 0.25 & 1.10 & 1.25 & 1.55 & 1.75 & 1.55 & 1.72 & 3.25 & 3.55 & 2.14 & 2.42 \\
\hline
\end{tabular}

In this respect, increases of yield and yield components specially the number of fully seeds /plant could be attributed to that beneficial effect of Seaweed to increase growth characteristics (Table, 1) and the photosynthetic pigments formation, as well $(T a b l e, 2)$ therefore, under these circumstances the translocation of different photosynthates from the source (leaves) to sink (seeds) is being maximized thereby, increase the number of fully seeds would be expected. Also, other studies reported that foliar application of seaweed liquid extract (Kelpak 66) enhanced bean yield by 24\% (Nelson and van Staden, 1984 and Wajahatullah Khan et al, 2009). The effect of amino acids as the main components of novavol and vegimax might be due to their roles in enhancing many physiological processes including nutrients uptake by roots and their metabolism in treated plants (Hanafy et al, 2010).. On the 
other hand, amino acids application has been reported to increase yield of faba bean [El-Ghamry et al, (2009) and Raeisi et al , (2013)], mung bean Bekata and Talat (2009).

\section{4- Minerals concentration:}

Data in Table (4) showed that mineral elements N, P,K, Mg, Ca, Fe and $\mathrm{Zn}$ concentration increased with different applied treatments i.e. seaweed at 1,2 and $4 \mathrm{ml} / /$, amino acids at 2,4 and $8 \mathrm{ml} / \mathrm{l}$ and the combination of seaweed at $2 \mathrm{ml} / \mathrm{l}+$ amino acids at $4 \mathrm{ml} / \mathrm{l}$, in leaves at 65 days after sowing during 2012 and 2013 seasons. The highest value of these elements was existed with seaweed at $2 \mathrm{ml} / \mathrm{l}+$ amino acids at $4 \mathrm{ml} / \mathrm{l}$.

Table (4).Effect of seaweed and amino acids treatments on mineral elements in common bean leaves (Phaseolus vulgaris L.) at 65 days after sowing during 2012 and 2013 seasons.

\begin{tabular}{|c|c|c|c|c|c|c|c|c|c|c|c|c|c|c|}
\hline \multirow{2}{*}{ Qharacteristics } & \multicolumn{2}{|l|}{$\mathrm{N} \%$} & \multicolumn{2}{|l|}{$\mathbf{P} \%$} & \multicolumn{2}{|l|}{$\mathrm{K} \%$} & \multicolumn{2}{|c|}{ Ca \% } & \multicolumn{2}{|c|}{ Mg \% } & \multicolumn{2}{|c|}{ Fe ppm } & \multicolumn{2}{|c|}{ Zn ppm } \\
\hline & 2012 & 2013 & 2012 & 2013 & 2012 & 2013 & 2012 & 2013 & 2012 & 2013 & 2012 & 2013 & 2012 & 2013 \\
\hline Seaweed at 1 & & & & & & & & & & & & & & \\
\hline $\mathrm{ml} / \mathrm{l}$ & 2.52 & 2.63 & 0.71 & 0.74 & 1.55 & 163 & 0.23 & 0.31 & 0.15 & 0.18 & 150 & 152 & 90.52 & 93.62 \\
\hline $\begin{array}{l}\text { Seaweed at } 2 \\
\mathrm{ml} / \mathrm{l}\end{array}$ & 2.66 & 2.74 & 0.75 & 0.78 & 1.62 & 1.69 & 0.24 & 0.36 & 0.18 & 0.21 & 155 & 161 & 92.30 & 95.78 \\
\hline $\begin{array}{l}\text { Seaweed at } 4 \\
\mathrm{ml} / \mathrm{l}\end{array}$ & 2.72 & 2.81 & 0.82 & 0.86 & 1.75 & 1.79 & 0.29 & 0.38 & 0.20 & 0.22 & 160 & 165 & 94.41 & 98.42 \\
\hline $\begin{array}{l}\text { Amino acids at } \\
2 \mathrm{ml} / \mathrm{l}\end{array}$ & 2.55 & 2.63 & 0.73 & 0.78 & 1.52 & 1.58 & 0.28 & 0.34 & 0.22 & 0.25 & 162 & 163 & 91.26 & 96.24 \\
\hline $\begin{array}{l}\text { Amino acids at } \\
4 \mathrm{ml} / \mathrm{l}\end{array}$ & 2.73 & 2.84 & 0.76 & 0.79 & 1.67 & 1.73 & 0.31 & 0.39 & 0.27 & 0.31 & 162 & 164 & 92.69 & 98.47 \\
\hline $\begin{array}{l}\text { Amino acids at } \\
8 \mathrm{ml} / \mathrm{l}\end{array}$ & 2.92 & 3.02 & 0.85 & 0.91 & 1.79 & 1.82 & 0.39 & 0.42 & 0.29 & 0.33 & 172 & 175 & 95.47 & 99.14 \\
\hline $\begin{array}{l}\text { Seaweed at } 2 \\
\mathrm{ml} / \mathrm{l}+\text { amino acid } \\
\text { at } 4 \mathrm{ml} / \mathrm{l}\end{array}$ & 3.05 & 3.15 & 0.93 & 0.96 & 1.98 & 2.14 & 0.45 & 0.52 & 0.31 & 0.35 & 182 & 191 & 99.65 & 100.3 \\
\hline Control & 2.32 & 2.41 & 0.62 & 0.65 & 1.31 & 1.41 & 0.15 & 0.21 & 0.11 & 0.14 & 130 & 134 & 81.20 & 85.19 \\
\hline LSD at $5 \%$ & 0.23 & 0.28 & 0.02 & 0.05 & 0.22 & 0.31 & 0.02 & 0.05 & 0.02 & 0.04 & 2.5 & 2.9 & 1.36 & 1.42 \\
\hline
\end{tabular}

The obtained increase of these elements could be attributed to different growth substances such as auxins promote growth, increase building metabolites, retard senescence, enhance cell division, chlorophyll accumulation and stimulate dry matter production as a result of higher photosynthetic activity and consequently increased translocation and accumulation of micro elements in plant organs Shafey et al (1994) and Chhun et al (2004). The effect of amino acids as the main components of novavol and vegimax might be due to their roles in enhancing many physiological processes including nutrients uptake by roots and their metabolism in treated plants, Hanafy et al. (2010).

In this respect, , Bekata and Talat (2009) Sprayed chamomile plant with amino acids (ornithine, proline or phenylalanine) increased total nitrogen $\%$ and crude protein, Bekata and Talat (2009). Also, amino acids 
increased total carbohydrates and total free amino acids in mung beanand snap bean, Abkader et al (2012).

\section{5- Some bioconstituents content:-}

In Table (5) data indicate that different applied treatments i.e. seaweed at 1,2 and $4 \mathrm{ml} / \mathrm{l}$, amino acids at 2, 4 and $8 \mathrm{ml} / \mathrm{l}$ and the combination of seaweed at $2 \mathrm{ml} / / \mathrm{l}+$ amino acids at $4 \mathrm{ml} / \mathrm{l}$ significantly increased total carbohydrates and crude protein in leaves at 65 days after sowing and in seeds at harvest time during 2012 and 2013 seasons. Also, seaweed at $2 \mathrm{ml} / \mathrm{l}+$ amino acids at $4 \mathrm{ml} / \mathrm{l}$ gave the highest value of the two constituents during 2012 and 2013 seasons.

Increases of carbohydrate and crude protein with applied of seaweed and amino acids has been reported in broad bean (Vicia faba L.) could be due to their important role in the biosynthesis of chlorophyll molecules which in turn affected total carbohydrates content by increasing photosynthates translocation from source to sink and increasing of different growth substances as well (Thomas et al, 2009).

Table (5).Effect of seaweed and amino acids treatments on total carbohydrates and crude protein contents in common bean leaves (Phaseolus vulgaris $L$.) at 65 days and crude protein in seeds at harvest time during 2012 and 2013 seasons.

\begin{tabular}{|c|c|c|c|c|c|c|}
\hline \multirow{4}{*}{ Treatments } & Total carbohydrates & hydrates & Crude protein & rotein & Crud & rotein \\
\hline & \multicolumn{4}{|c|}{$\%$} & \multicolumn{2}{|c|}{$\%$} \\
\hline & \multicolumn{4}{|c|}{ In leaves at 65 days } & \multicolumn{2}{|c|}{$\begin{array}{l}\text { In seeds at } \\
\text { harvest time }\end{array}$} \\
\hline & 2012 & 2013 & 2012 & 2013 & 2012 & 2013 \\
\hline Seaweed at $1 \mathrm{ml} / \mathrm{l}$ & 40.25 & 40.62 & 15.75 & 16.44 & 20.15 & 21.15 \\
\hline Seaweed at $2 \mathrm{ml} / \mathrm{l}$ & 41.29 & 42.82 & 16.63 & 17.13 & 21.14 & 22.14 \\
\hline Seaweed at $4 \mathrm{ml} / \mathrm{l}$ & 43.42 & 43.91 & 17.00 & 17.56 & 22.16 & 23.26 \\
\hline Amino acids at $2 \mathrm{ml} / \mathrm{l}$ & 44.65 & 44.71 & 15.94 & 16.44 & 21.18 & 22.57 \\
\hline Amino acids at $4 \mathrm{ml} / \mathrm{l}$ & 46.32 & 47.23 & 17.06 & 17.75 & 23.09 & 24.78 \\
\hline Amino acids at $8 \mathrm{ml} / \mathrm{l}$ & 47.75 & 48.82 & 18.25 & 18.88 & 24.76 & 25.91 \\
\hline $\begin{array}{l}\text { Seaweed at } 2 \mathrm{ml} / \mathrm{l}+\text { amino acid } \\
\text { at } 4 \mathrm{ml} / \mathrm{l}\end{array}$ & 48.52 & 49.85 & 19.06 & 19.69 & 26.12 & 27.65 \\
\hline Control & 35.21 & 336.21 & 14.50 & 15.06 & 18.72 & 19.12 \\
\hline LSD at $5 \%$ & 1.31 & 1.45 & 1.25 & 1.32 & 1.10 & 1.23 \\
\hline
\end{tabular}




\section{REFERANCES}

A.O.A.C., 1990. Official Method of Analysis, 15th Ed., Association of Official Analytical Chemists, Inc., USA.

Abdelkader AF, Hassanein RA, Heba Ali. (2012). Studies on effects of salicylic acid and thiourea on biochemical activities and yield production in wheat (Triticum aestivum var. Gimaza 9) plants grown under drought stress. African J. of Biotech. 11(64):1272812739.

Abdel-Mawgoud, A.M.R., A.S. Tantawy, M.M. Hafez and H.A.M. Habib, (2010). Seaweed extract improves growth, yield and quality of different watermelon hybrids", Res. J. of Agric. and Biol. Sci., 6(2): 161-186.

Abo Sedera, F.A., A.A. Abd El-Latif, L.A.A. Bader and S.M. Rezk ( 2010. ) Effect of NPK mineral fertilizer levels and foliar application with humic and amino acids on yield and quality of strawberry", Egyp.J. of Appl. Sci., 25: 154-169.

Abou El-Yazied, A., A.M. El-Gizawy, M.I. Ragab and E.S. Hamed, (2012). Effect of seaweed extract and compost treatments on growth, yield and quality of snap bean", J. of Am. Sci., 8(6): 1-20.

Alcázar R, Altabella T, Marco F, Bortolotti C, Reymond M, Koncz C, Carrasco P,Tiburcio AF. Polyamines: (2010).Molecules with regulatory functions in plant abiotic stress tolerance. Planta;231:1237-1249.

Bekheta, MA, Talaat, IM. (2009). Physiological response of mung bean "Vigna radiata" plants to some bioregulators. J. Of Applied Botany and Food Quality.;83,1;76-84.

Bidwell, R. G. S. (1980). Plant Physiology. $2^{\text {nd }}$ Ed., Callier MacMillan Publisher, London, New York.

Chhun T, Takcta S, Tsurumi S, Masahiko I. (2004). Different behaviour of indole-3-acetic acid and indole-3-butyric acid in stimulating lateral root development in rice (Oryza sativa L.).Plant Growth Regul.43:135-143.

Crouch IJ, Staden VJ. (1993). Evidence for the presence of plant growth regulators in commercial seaweed products. Plant Growth regulators 13:21-29.

Crouch IJ, van Staden J (1992) Effect of seaweed concentrate on the establishment and yield of greenhouse tomato plants. J Appl Phycol 4:291-296.

Crouch, I . J. and Van-Staden, J. (1993). Evidence for the presence of plant growth regulators in commercial seaweed products. Plant Growth Regul. 13: 2129.

Crouch, I.J. (1990). The effect of seaweed concentrate on plant growth. Dissertation for doctor of philosophy. Dept. Botany. Univ. Natal, Pietermaritzburg. South Africa.

Demir, D., Günes, A., Inal, A. and Alpaslan, M. (2004). Effects of humic acids on the yield and mineral nutrition of cucumber (cucumis sativus I.) grown with different salinity levels.ishs acta horticulturae 492 . 
Derieux, M., R. Kerrest and Y. Montalanty, 1973. Etude de la surface foliaive et de lactivite photosynthetique chez kulkues hybrids de mais", Ann. Amelior plants, 23: 95-107.

Dhargalkar VK and Pereira N (2005). Seaweed. Promising plant of the millennium. Scince.

Dubios, M., K.A. Gilles, J.K. Hamilton, P.A. Rebe ns and F. Smith, 1956. "Colorimetric method for determination sugars and related substances", Anal. Chem. Soc., 46: 1662-1669.

El-Desouky, S.A., F.H. Ismaeil, A.L.Wanas, E-S. L. Fathy and M.M. AbdEIAll, (2011). Effect of yeast extract, amino acids and citric acid on physioanatomical aspects and productivity of tomato plants grown in late summer season", Minufiya J. Agric. Res., 36(4): 859-884.

El-Ghamry, A. M.; Abd El-Hai, K. M. and Ghoneem, K. M. (2009). Amino and humic acids promote growth, yield and disease resistance of faba bean cultivated in clayey soil. Austr. J. of Basic and Appl. Sci., 3(2):731-739.

Fletcher, R. A., Hofstra, G. and Gao, J. (1988). Comparative fungitoxic and plant growth regulating properties of triazole derivatives. Plant Cell Physiology 27: 367- 371.

Garbaye, J., and Churin, J.L. (1996). Effect of ectomycorrhizal inoculation at planting on growth and foliage quality of Tilia tomentosa. J.Arboric. 22(1):29-33.

Hanafy Ahmed, A. H.; Nesiem, M. R.; Hewedy, A. M. and Sallam, H. El-S. (2010). Effect of some Simulative Compounds on Growth, Yield and Chemical Composition of Snap Bean Plants Grown under Calcareous Soil Conditions, journal of American Science, 6(10)552-569.

Horneck, D.A. and D. Hanson, 1998. "Determination of potassium and sodium by Flame Emission Spectrophotometry", In Handbook of Reference Methods for Plant Analysis, pp: 153-155.

Horneck, D.A. and R.O. Miller, 1998. "Determination of total nitrogen in plant tissue", In Handbook of Reference Methods for Plant Analysis,pp:75-83.

Hussein MS, El Sherbeny SE and Abou Leila BH (1992) Effect of some basic nitrogen compounds on the growth, photosynthetic pigment and alkaloid content in Datura metal L. Egypt. J. Physiol. Sci., 16 (1 -2): 141-150.

Jackson, M.L.,1967.Soil chemical analysis", prentic hallpvt. Itd. India, pp: 398.

Khan, W., U.P. Rayirath, S. Subramanian, M.N. Jithesh, P.Rayorath, D.M. Hodges, A.T. Critchley, J.S. Craigie,J. Norrie, B. Prithivira, (2009). Seaweed extracts as bio stimulants of plant growth and development", J. Plant Growth Regul., 28: 386-399.

Marschner, H.,(1995).Mineral nutrition of higher plants", 2nd ed.London,UK: Academic Press. Nelson, N., (1944). "A photomorphic adaption of the semogyi method for determine of glucose", J. Biol. Chem., 153:373-377.

Nelson WR, van Staden J (1984) The effect of seaweed concentrate on wheat culms. J. Plant Physiol. 115:433-437.

Nelson, E. T., and. Orcutt, D.M.(1996). Physiology of plants under stress: abiotic factors. John Wiley \& Sons., New York. 
Nelson, W. R. and Van Staden, J. (1984). The effect of seaweed concentrate on the growth of nutrient-stressed, greenhouse cucumbers. Hort. Science 19: 81- 82.

Öpik ,H. and S. Rolfe (2005):The Physiology of flowering plants .Cambridge Univ.Pres 5.Plant Growth hormones pp:177-194.

Piper, G.S., 1947. "Soil and plant analysis. The Univ. of Adelaide, Adelaide".

Raeisi M, Farahani L, Shams S. (2013). Effects of chemical fertilizers and bio stimulants containing amino acid on yield and growth parameters of broad bean (Vicia faba L.). Intern. J. of Agricu. and Crop Sci;5(21):2618-2621.

Sandell, R., 1950. "Colorimetric determination of traces of metal", 2ndEd. Interscience pub., Inc. New York.

Schmidt, R.E. ( 2005). biostimulants function in turfgrass nutrition. phd emeritus virginia tech.

Şehirali, S. (1988). Yemeklik tane baklagiller Ders Kitabı.(Seed Legumes, Lecture Notes), Publication No. 1089 pp.314. Faculty of Agriculture, University of Ankara, Turkey.

Shafey SA, Salem MSA, Yassien HE, (1994). Harb OMS. Effect of indole 1-3 acetic acid (IAA) on growth and yield of some Egyptian wheat varieties. J. Agric. Sci. Mansoura Univ. 19(12):4113-4120.

Shehata, S.M., H.S. Abdel-Azem, H.S. Abou El-Yazied and A.M. El-Gizawy, (2011). Effect of foliar spraying with amino acids and seaweed extract on growth chemical constitutes, yield and its quality of celeriac plant", European J. of Sci. Res., 58(2): 257-265.

Smirnoff, N. (1996). The function and metabolism of ascorbic acid in plant. Annals of Botany. 78:661-669.

Smirnoff, N. (2000). Ascorbate biosynthesis and function in photoprotection. Phil Trans R Soc Lond B 355:1455-1464.

Smirnoff, N., (1995). Antioxidant systems and plant response to the environment. In N. Smirnoff (Ed.), Environment and plant metabolism: Flexibility and acclimation (pp. 217-243). Oxford, UK: BIOS Scientific Publishers Ltd.

Snedecor, G.W. and W.G. Cochran (1980): Statistical Methods. $7^{\text {th }}$ ed. The lowa state. Univ. Press, Ames, lowa, U.S.A.

Wajahatullah Khan ; Usha P. Rayirath ; Sowmyalakshmi Subramanian ;Mundaya N. Jithesh ; Prasanth Rayorath ; D. Mark Hodges ;Alan T. Critchley ;James S. Craigie ; Jeff Norrie and Balakrishan Prithiviraj (2009). Seaweed Extracts as Biostimulants of Plant Growth and Development, J. Plant Growth Regul 28:386-399.

Waller, G. R. and Nowaki, E. K. (1978). Alkaloid, Biology and Metabolism in Plants. Plenum Press, New York, 85-247 pp.

Wettstein, D., 1957. "Chlorophyll, letal und der submicroskpische formmech sell-der-plastiden", Exptl. Cell. Res., 12: 427.

Yan, J. (1993). Influence of plant growth regulators on turfgrass polar lipid composition, tolerance to drought and saline stresses, and nutrient efficiency. Ph.D.. Dissertation. CSES, Virginia Tech. 
Yan, S.D., Schmidt, A.M., Anderson, G.M., Zhang, J., Brett, J., Zou, Y.S., Pinsky, D. and Stern, D. (1994). Enhanced cellular oxidant stress by the interaction of advanced glycation end products with their receptor/binding proteins. J Biol Chem 269: 9889-9897, 1994.

Zhang X and Schmidt RE (1997) The impact of growth regulators on the atocopherol status in water-stressed Poa pratensis L. Int Turfgrass Res J 8:1364-1373.

Zhang, S., J. Weng, J. Pan, T. Tu, S. Yao and C. Xu (2003). Study on the photogeneration of superoxide radicals in Photosystem II with EPR spin trapping techniques. Photosynth Res. 75:41-48.

Zhang, X. and Schmidt, R.E. (2000). Hormone-containing products' impact on antioxidant status of tall fescue and creeping bentgrass subjected to drought. Crop Science, v.40, p.1344-1349

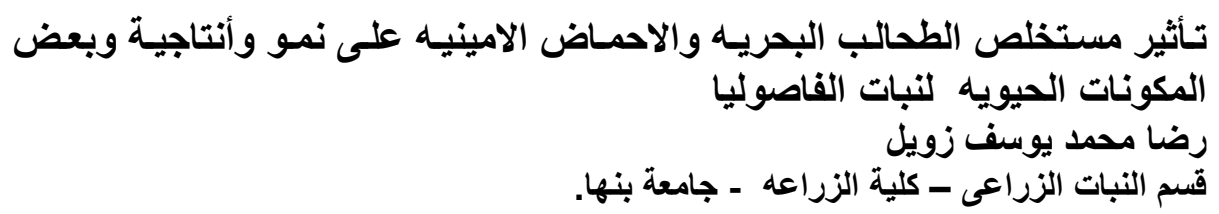

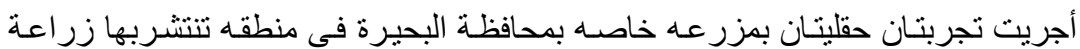

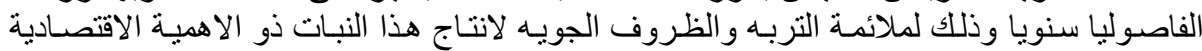

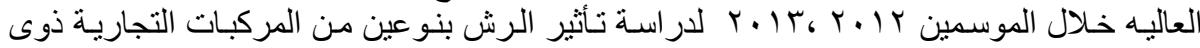

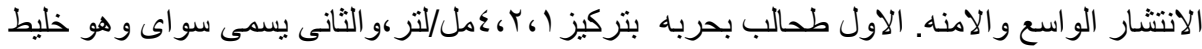

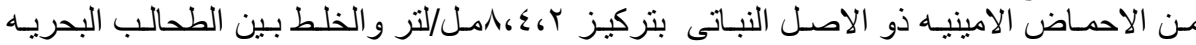

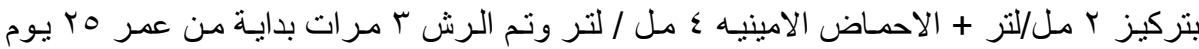

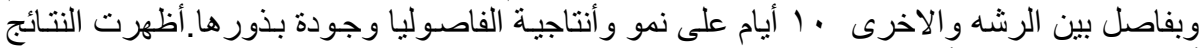

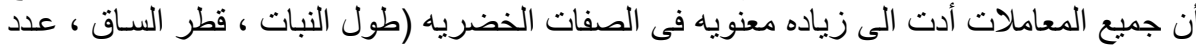

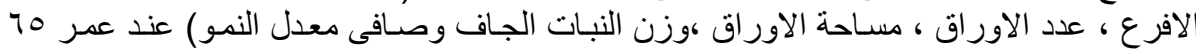

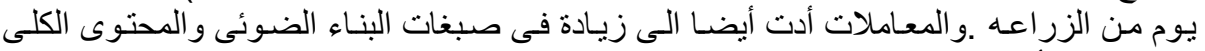

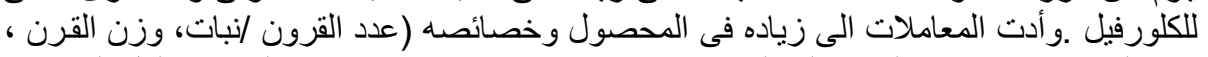

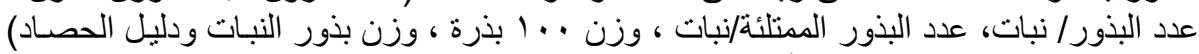

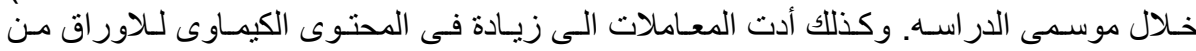

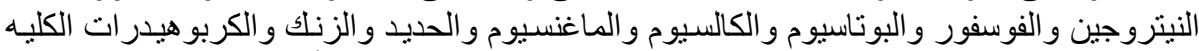

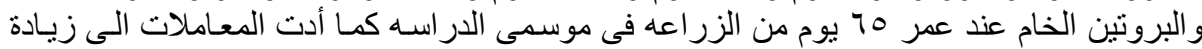

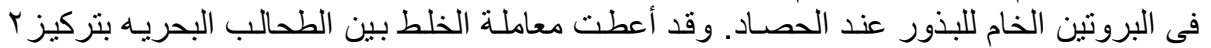
مل/لتر + الاحماض الامينيه ؛ مل/ لتر أعلى نتائج فى جميع الصفات لـات خلال موسمى الدراسه. 
Zewail, R. M. Y. 
J. Plant Production, Mansoura Univ., Vol. 5 (8): 1441 - 1453, 2014

Corresponding authors: Reda Zewail Botany Dpt., Fac. Agric. Benha Univ. Egypt. Website: www..bu.edu.eg/staff member/reda.zewail6 edu mail: Reda.zewail@fagr.bu.edu.eg 